\title{
The Effect of Live Food on the Coloration and Growth in Guppy Fish, Poecilia reticulata
}

\author{
Elsah Arce Uribe ${ }^{1 *}$, Marco Polo Franco Archundia ${ }^{2}$, Jorge Luna-Figueroa ${ }^{1}$ \\ ${ }^{1}$ Laboratorio de Acuicultura, Departamento de Hidrobiología, Centro de Investigaciones Biológicas, Universidad Autónoma del \\ Estado de Morelos, Cuernavaca, Morelos, México \\ ${ }^{2}$ Maestría en Manejo de Recursos Naturales, Centro de Investigaciones Biológicas, Universidad Autónoma del Estado de Morelos, \\ Cuernavaca, Morelos, México \\ Email: *elsah.arce@uaem.mx, biol.marcofranco@hotmail.com, jluna@uaem.mx
}

How to cite this paper: Arce, E., Archundia, M.P.F. and Luna-Figueroa, J. (2018) The Effect of Live Food on the Coloration and Growth in Guppy Fish, Poecilia reticulata. Agricultural Sciences, 9, 171-179. https://doi.org/10.4236/as.2018.92013

Received: August 30, 2017

Accepted: February 6, 2018

Published: February 9, 2018

Copyright $\odot 2018$ by authors and Scientific Research Publishing Inc. This work is licensed under the Creative Commons Attribution International License (CC BY 4.0).

http://creativecommons.org/licenses/by/4.0/ (c) (i) Open Access

\begin{abstract}
Colour production in fish is due mostly to food. In conditions of captivity, the type of food is restricted, while various types of food are used in aquaculture, from processed dry food to small aquatic animals. In this study, we used nauplii of Artemia franciscana, "water fleas" Moina wierzejski, micro-worm Panagrellus redivivus, and commercial flakes. We used Poecilia reticulata, which is one of the most traded fish in ornamental aquaculture and hypothesise that if the live food influences the coloration and growth of $P$. reticulata, there must be differences in the intensity of colour pattern and growth rate in fish fed with different living animals. Consistent with our prediction, females and males of $P$. reticulata were more colourful when they were fed on $A$. franciscana, $P$. redivivus and $M$. wierzejski than when they were fed commercial flakes. Females and males of $P$. reticulata fed with $A$. franciscana grew in less time than fish fed with $P$. redivivus, $M$. wierzejski, or commercial flakes. We conclude that live food is an excellent way to affect growth and coloration in fish.
\end{abstract}

\section{Keywords}

Coloration, Growth Rate, Artemia franciscana, Moina wierzejski, Panagrellus redivivus

\section{Introduction}

Food is critical for all features of individuals. Colour production in fish is due mostly to food. In some animals like fish, coloration is used to indicate immune states [1], camouflage helps to detect predators and when stalking prey [2] [3] and it is a character used in sexual selection [4]. In many animals, colour is 
determined by the quality and quantity of food eaten, for instance, molluscs nurtured with carotenoid pigments [5] or crustaceans with Hibiscus sabdariffa in their food to increase their colour pattern [6]. In fish, feeding depends on several factors, such as the type of mouth, which is determined by the site of the water column in which the animal lives [7] [8]; age, which defines the size and type of food that the fish can ingest [9]; food availability, which is determined by the seasons in which the environment has a higher quantity and quality nutrients in the water [10]; and the number of individuals that compete for food resources in a specific area [11]. Colour is an attribute that is regulated by genetics and environmental conditions. Fish obtain coloration from carotenoids found in different foods [12]. When the animals eat, the pigment is saved directly to the skin, which is where the chromatophores are located; these cells reflect the coloration [13]. Feeding in fish is crucial from ecological and ornamental context. In conditions of captivity the most important animals used as live feeds are nauplii of Artemia franciscana [14], and mosquito larvae, Culex quinquefasciatus and C. stigmatosoma [15]. Other cultured animals for feeding are commonly known as "water fleas", Moina wierzejski and Daphnia pulex [16], and the micro-worm Panagrellus redivivus [17].

Poecilia reticulata is one of the most traded fish in ornamental aquaculture; there are many varieties which are characterised by the colour pattern. As in other species, coloration in P. reticulata could indicate immune status and is an important character in mate choice. This species is one of the most studied fish for their ecological and ornamental importance. We evaluated the effect of live food in the coloration and growth of $P$. reticulata, and we hypothesize that if live food influences the coloration and growth of $P$. reticulata, there will be differences in the intensity of the colour pattern and growth rate in fish fed with different living animals.

\section{Materials and Methods}

\subsection{Experimental Diets}

Four experimental diets were used containing different nutrients. Three of the experimental diets were cultured in the laboratory. The water flea, $M$. wierzejski, was grown in fiberglass ponds fertilised with chicken manure (50\% protein, $19.37 \%$ lipids, and $4.12 \%$ carbohydrates) [18]. The micro-worm, $P$. redivivus, was grown in plastic containers with water-oatmeal (44.22\% protein, $11.31 \%$ lipids, and 5.22\% carbohydrates) [18]. Nauplii of $A$. franciscana were hatched in glass bottles in water at 35 ups $(57.26 \%$ protein, $16.21 \%$ lipids, and $6.67 \%$ carbohydrates) [18]. The other diet was commercial flakes (45\% protein, $4.5 \%$ lipids, and $5.0 \%$ carbohydrates). All cultures were maintained at $28^{\circ} \mathrm{C} \pm 2^{\circ} \mathrm{C}$.

\subsection{Maintenance of the Animals}

Fish were descendants by reproduction in the laboratory. Fish were obtained 
randomly at 30 days old from the same population of offspring of a pair of guppies, $P$. reticulata. Physical and chemical conditions of the water were: $25^{\circ} \mathrm{C} \pm$ $0.5^{\circ} \mathrm{C}, \mathrm{pH} 7.2 \pm 0.1,154.5 \mathrm{mg} \cdot \mathrm{L}^{-1} \mathrm{CaCO}_{3}$ and $5.5 \pm 0.5 \mathrm{mg} \cdot \mathrm{L}^{-1} \mathrm{O}_{2}$. Food waste and feces were removed by siphon daily.

\subsection{Experimental Protocol}

Physical and chemical conditions of the water were the same as those used during acclimatization. Fish were randomly divided into four experimental groups and two replicates $(\mathrm{n}=216)$. At the start of the experiment, fish were placed in $20 \mathrm{~L}$ tanks and fed daily ad libitum twice a day with each of the experimental diets. At 90 days the fish were removed of the experiment and the Absolute Growth Rate (AGR) was estimated as the difference between the final and the initial size, divided by the duration of the experiment. Fish were weights with a plate balance (OHAUS; $0.01 \mathrm{~g}$ ), measured with callipers $(0.01 \mathrm{~mm}$ ), and sex was determined by the identification of gonophores.

\subsection{Colour Measurements and Statistical Analyses}

At the end of the experiment, each fish was introduced into a photographic tank $(10 \times 10 \times 1 \mathrm{~cm})$. All of the walls of this tank were white. Each fish was photographed 3 times in a plane parallel to the body using a camera (Panasonic DMC-GH4). All pictures were converted into 8-bit greyscale [19] and analysed for colour using ImageJ software [20]. This software detects intensity of the colour of an image in a grayscale; it is used in the digital image and in this case, the value of each pixel (PX) has a value equivalent to a grayscale. Each pixel is assigned a number between 0 and 255. The value 0 represents the black and the value 255 represents the white. Values closer to cero denote a higher intensity of colour and vice versa. The coloration and growth were evaluated using General linear models (GLM). To specify which means were significantly different from one another, we performed a Tukey post hoc test [21]. All statistical analyses were conducted using Statistics 10 Software.

\section{Results}

The survival rate of the test animals was $100 \%$. Fish used in the analysis of colour at the end of the experiment did not different in size and weight in females or males $(P>0.05)$. Females and males of $P$. reticulata were more colourful when they fed with $A$. franciscana, $P$. redivivus and $M$. wierzejski than when they fed with commercial flakes $\left(\mathrm{F}_{(3,116)}=19.40, P<0.001 ; \mathrm{F}_{(3,100)}=21.78, P<\right.$ 0.001; Figure 1(A) and Figure 1(B) respectively). Colour intensity between females and males did not differ in the animals fed with $A$. franciscana, $P$. redivivus and $M$. wierzejski; colour intensity between females and males was different in the fish fed with commercial flakes $\left(\mathrm{F}_{(7,216)}=19.10, P<0.001\right)$.

Females and males of $P$. reticulata fed with $A$. franciscana grew in less time than fish fed $P$. redivivus and $M$. wierzejski. The animals fed with commercial 


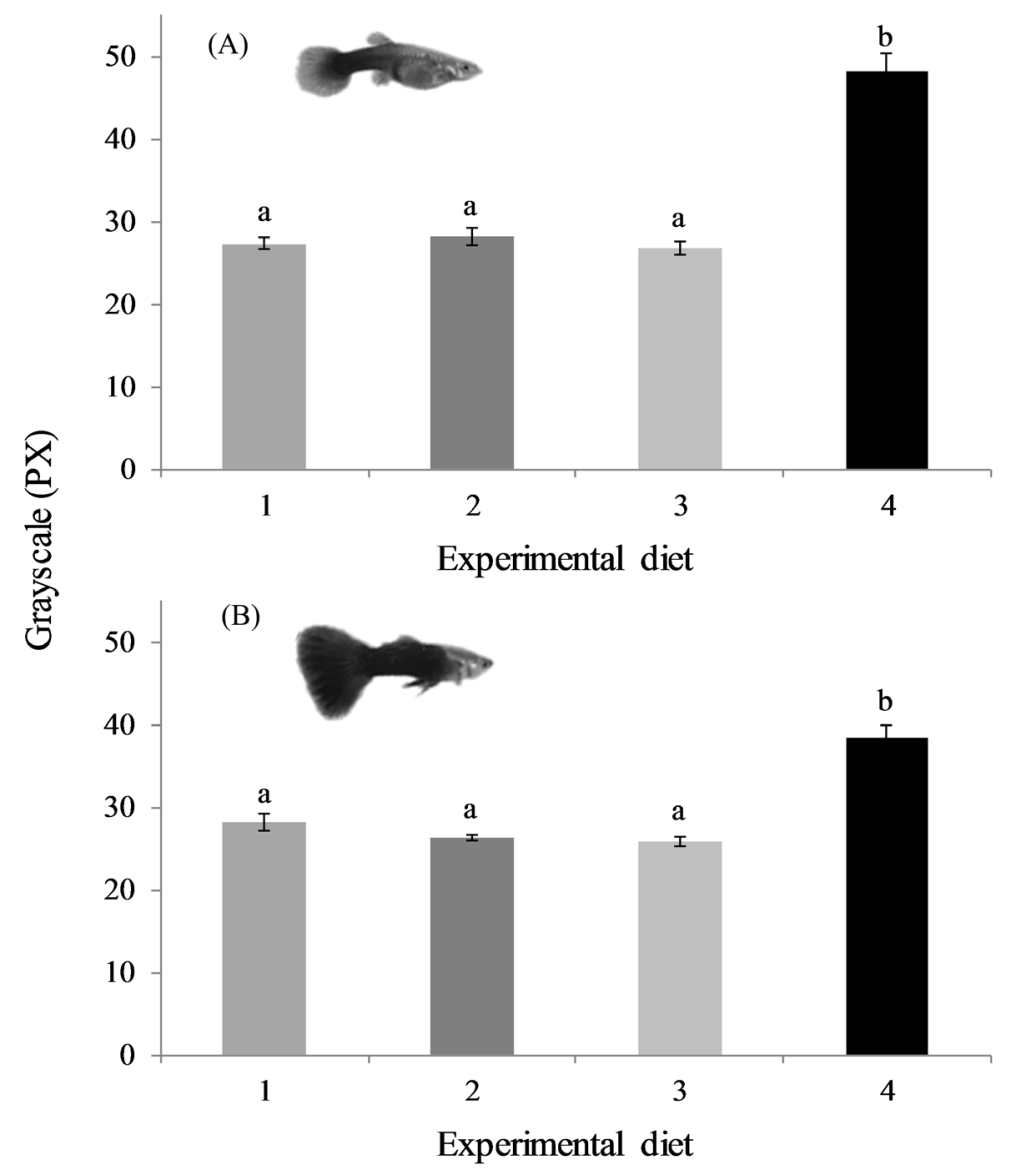

Figure 1. Coloration in $P$. reticulata fed with the four experimental diets: 1) A. franciscana, 2) $P$. redivivus, 3) $M$. wierzejski, and 4) commercial flakes. Letters indicated statistical differences $(P<0.01)$. Mean values and standard error are shown; a value closer to 0 represents a higher intensity of black color. A indicates females and $\mathrm{B}$ indicates males.

flakes in both genders grew longer than the other experimental diets $\left(\mathrm{F}_{(3,116)}=\right.$ 7.13, $P<0.001 ; \mathrm{F}_{(3,100)}=8.38, P<0.001$; Figures $\left.2(\mathrm{~A})-(\mathrm{B})\right)$.

\section{Discussion}

High percentages of survival determine the success in the production of fish species with economic potential. The survival rate of the test animals was $100 \%$ for all diets used. Coloration is a cue for communication. Some animals, like fish, display carotenoid-based ornaments which are considered an honest signal of the body condition and parasite resistance [19] [22]. For example, studies showed that carotenoid-based coloration is related to social dominance [23]. Fish must obtain carotenoid pigments from their diet. Females and males of $P$. reticulata were more colourful when fed $A$. franciscana, $P$. redivivus and $M$. wierzejski than when they were fed with commercial flakes. Although flakes supplied in the experiments have a high nutritional value, coloration was more intense in fish that consume any live food. This difference could be the result of 


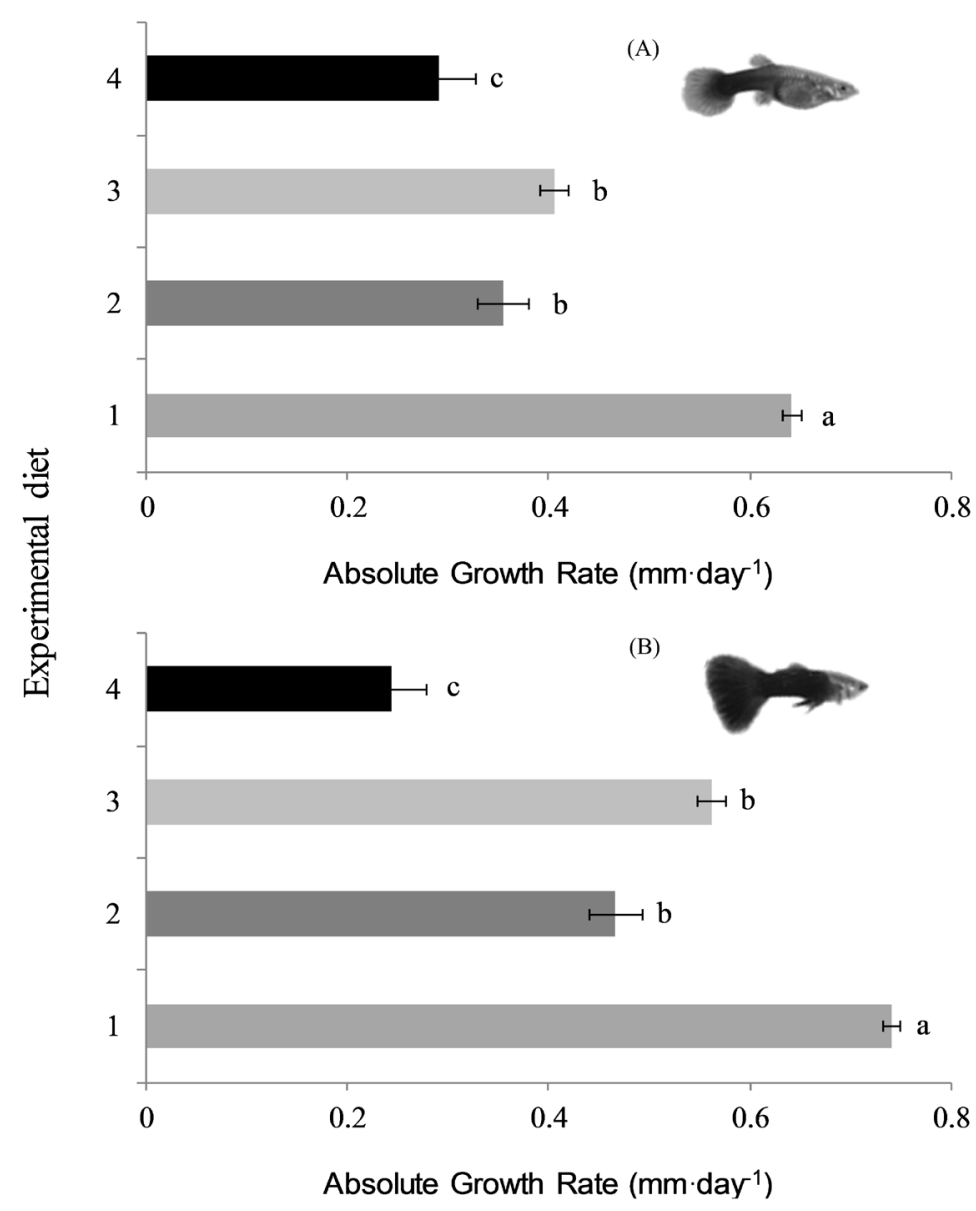

Figure 2. Growth in $P$. reticulata fed with the four experimental diets: 1) $A$. franciscana, 2) $P$. redivivus, 3) $M$. wierzejski, and 4) commercial flakes. Letters indicated statistical differences $(P<0.01)$. Mean values and standard error are shown; A indicates females and B indicates males.

the diet digestibility and in stimulating fish catches. Additionally, the live food does not undergo drying processes, freezing, or packaging, which decreases its original value [24] [25] [26]. On the other hand, increasingly colour intensity using live food in comparison with commercial flakes could be attributed to crustacean used ( $M$. wierzejski and $A$. franciscana) which are filter feeders, so they obtain sources of carotenoids from microalgae present in cultured [27] [28] [29].

Growth is a good indicator of the health of an organism [30]. The growth rate of fish is affected by food quality, which is essentially determined by protein quality [31]. In this study, females and males of $P$. reticulata fed with $A$. franciscana grew in less time than the fish fed $P$. redivivus and $M$. wierzejski. In contrast, in both genders, animals fed with commercial flakes took longer to grow than the other experimental diets with live food. Live food is a capsule that contains the basic elements of a balanced diet with the advantage that it retains its value to be eaten by fish (i.e., remains undissolved in contact with water). 
Some studies have found that the growth is increased with live food in contrast with commercial flakes [12] [32] [33] [34]. Live food like A. salina, Tubifex tubifex, D. pulex, Brachionus plicatilis, and $C$. pipiens have differences in protein digestibility; these differences are due to the enzymes present in them. Artemia nauplii are an essential diet for fish with aquaculture potential [35]. However, Artemia nauplii quality varies with the strain, location, and season [36]. Additionally, Artemia nauplii are expensive and there is variation in availability, so we proposed Moina and Panagrellus as alternative of live food for aquaculture [37] [38]. Moina are crustaceans with high quality, and fast growth and reproduction. In this research, we showed that live food is an excellent alternative for aquaculture, all live food options are potentially usable for ornamental fish production, and we demonstrate a positive effect of live food in coloration and growth in $P$. reticulata.

\section{Acknowledgements}

The authors thank J. Figueroa and S. Esposito for the technical support in the laboratory experiments. Thanks also to M. Torres for the pictures analysis. Academic and Scientific Editing and Proofreading Services edited this English-language text.

\section{References}

[1] Grether, G.F., Kasahara, S., Kolluru, G.R. and Cooper, E.L. (2003) Sex-Specific Effects of Carotenoid Intake on the Immunological Response to Allografts in Guppies (Poecilia reticulata). Proceedings of the Royal Society of London, 271, 45-49. https://doi.org/10.1098/rspb.2003.2526

[2] Randall, J.E. (2005) A Review of Mimicry in Marine Fishes. Zoological Studies, 44, 299-328.

[3] Cheney, K.L., Grutter, A.S. and Marshall, N.J. (2007) Facultative Mimicry: Cues for Colour Change and Colour Accuracy in a Coral Reef Fish. Proceedings of the Royal Society, 275, 117-122. https://doi.org/10.1098/rspb.2007.0966

[4] Maan, M.E., Seehausen, O., So“derberg, L., Johnson, L., Ripmeester, E.A.P., Mrosso, H.D.J., Taylor, M.I., van Dooren, T.J.M. and van Alphen, J.J.M. (2004) Intraspecific Sexual Selection on a Speciation Trait, Male Coloration, in the Lake Victoria Cichlid Pundamilia nyererei. Proceedings of the Royal Society of London, 271, 2445-2452. https://doi.org/10.1098/rspb.2004.2911

[5] Canales-Gómez, E., Correa G. and Viana, M.T. (2010) Efecto de la adición de tres pigmentos carotenoides comerciales (astaxantina, cantaxantina y $\beta$-caroteno) en la dieta sobre la coloración de la concha o nácar de juveniles de abulón rojo Haliotis rufescens. Veterinaria México, 41, 191-200.

[6] Aréchiga, M., Moreno, A.D., Gil, G.L., Montoya, C.E., Chong, O., Vargas, M.A. and Vega, F. (2015) Inclusión de Hibiscus sabdariffa en alimentos experimentales para Macrobrachium tenellum: efectos en la pigmentación, crecimiento y supervivencia. e-Gnosis, 13, 1-14.

[7] Ruiz, L.J., Prieto, A. and Lemus. M. (2001) Morfología bucofaríngea y hábitos alimentarios de Micropogonias furnieri (Pisces: Sciaenidae) en la costa norte del Estado Sucre, Venezuela. Revista de Biología Tropical, 49, 903-913. 
[8] Pelegrin, N. and Haro. J.G. (2004) Ecología alimentaria de Parodon tortuosus (Pisces, Characiformes) en el río de la Suela (Córdoba, Argentina). Ecología Austral, 14, 45-51.

[9] Franco, A.M.P. and Luna-Figueroa, J. (2015) Consumo de pre-adultos de mosquitos por peces ornamentales. Avances en Investigación Agropecuaria, 19, 53-67.

[10] Kandemir, S. and Polat, N. (2007) Seasonal Variation of Total Lipid and Total Fatty Acid in Muscle and Liver of Rainbow Trout (Oncorhynchus mykiss W., 1792) Reared in Derbent Dam Lake. Turkish Journal of Fisheries and Aquatic Sciences, 7, 27-31.

[11] Atencio-García, V. and Zambori-Fiho, E. (2006) The Cannibalism in the Fish Larviculture. Revista $M V Z$ Córdoba, 11, 9-19.

[12] Yuangsoi, B., Jintasataporn, O., Areechon, N. and Tabthipwon, P. (2010) The Use of Natural Carotenoids and Growth Performance, Skin Pigmentation, and Immune Response in Fancy Carp (Cyprinus carpio). Journal of Applied Aquaculture, 22, 267-283. https://doi.org/10.1080/10454438.2010.500602

[13] Blount, J.D., Metcalfe, N.B., Birkhead, T.R. and Surai, P.F. (2003) Carotenoid Modulation of Immune Function and Sexual Attractiveness in Zebra Finches. Science, 300, 125-127. https://doi.org/10.1126/science.1082142

[14] Divya, K.R., Isamma, A., Arunjith, T.S., Sureshkumar, S. and Krishnakumar, V. (2014) Effect of Enriched Artemia franciscana on Production, Survival, Growth and Biochemical Composition of the Freshwater Fish Catla catla (Hamilton, 1922). International Journal of Recent Biotechnology, 2, 15-24.

[15] Workman, D.P. and Walton, W.E. (2003) Larval Behaviour of Four Culex (Diptera: Culicidae) Associated with Treatment Wetlands in the Southwestern United States. Journal of Vector Ecology, 28, 213-228.

[16] Echaniz, S.A. and Vignatti, A.M. (2010) Diversity and Changes in the Horizontal Distribution of Crustaceans and Rotifers in an Episodic Wetland of the Central Region of Argentina. Biota Neotropica, 10, 133-141. https://doi.org/10.1590/S1676-06032010000300014

[17] Luna-Figueroa, J. (2009) Nematodo de vida libre Panagrellus redivivus (Goodey, 1945): Una alternativa para la alimentación inicial de larvas de peces y crustáceos. Investigación y Ciencia, 45, 4-11.

[18] Luna-Figueroa, J., Vargas, Z.D.J. and Figueroa, T.J. (2010) Alimento vivo como alternativa en la dieta de larvas y juveniles de Pterophyllum scalare (Lichtenstein, 1823). Avances en Investigación Agropecuaria, 14, 63-72.

[19] Schweitzer, C., Motreuil, S. and Dechaume-Moncharmont, F.X. (2015) Coloration Reflects Behavioural Types in the Convict Cichlid, Amatitlania siquia. Animal Behaviour, 105, 201-209. https://doi.org/10.1016/j.anbehav.2015.04.024

[20] Schneider, C.A., Rasband, W.S. and Eliceiri, K.W. (2012) NIH Image to ImageJ: 25 Years of Image Analysis. Nature Methods, 9, 671-675. https://doi.org/10.1038/nmeth.2089

[21] Zar, J.H. (2010) Biostatistical Analysis. 5th Edition, Prentice Hall, Englewood Cliffs, NJ, 944 p.

[22] Valente, L.M.P., Araújo, M., Batista, S., Peixoto, M.J., Sousa-Pinto, I., Brotas, V., Cunha, L.M. and Rema, P. (2015) Carotenoid Deposition, Flesh Quality and Immunological Response of Nile Tilapia Fed Increasing Levels of IMTA-Cultivated Ulva spp. Journal of Applied Phycology, 28, 691-701.

https://doi.org/10.1007/s10811-015-0590-9 
[23] Wisenden, B.D., Stumbo, A.D., Self, P.A., Snekser, J.L. McEwen, D.C., Wiseden, P.A., Keenleyside, M.H.A., Itzkowitz, M. and Brisch, E. (2015) Co-Evolution of Offspring Anti-Predator Competence and Parental Brood Defense in Convict Cichlids. Hydrobiologia, 748, 259-272. https://doi.org/10.1007/s10750-014-1917-2

[24] Coutteau, P. and Sorgeloos, P. (1992) The Use of Algal Substitutes and the Requirement for Live Algae in the Hatchery and Nursery Rearing of Bivalve Molluscs: An International Survey. Journal of Shellfish Research, 11, 467-476.

[25] García-Ortega, A. (2000) Valor nutricional de los quistes de Artemia y su uso como fuente de proteína en dietas artificiales para larvas de peces. In: Cruz-Suárez, L.E., Ricque-Marie, D., Tapia-Salazar, M., Olvera-Novoa, M.A. and Civera-Cerecedo, R., Eds., Avances en nutrición acuícola V. Memorias del V Simposium Internacional de Nutrición Acuícola, 19-22.

[26] Glencross, B.D., Booth, M. and Allan, G.L. (2007) A Feed Is Only as Good as Its Ingredients-A Review of Ingredient Evaluation Strategies for Aquaculture Feeds. Aquaculture Nutrition, 13, 17-34. https://doi.org/10.1111/j.1365-2095.2007.00450.x

[27] Delgado-Vargas, F., Jiménez, A.R. and Paredes-López, O. (2000) Natural Pigments: Carotenoids, Anthocyanins, and Betalains-Characteristics, Biosynthesis, Processing, and Stability. Critical Reviews in Food Science and Nutrition, 40, 173-289. https://doi.org/10.1080/10408690091189257

[28] Pan, C.H., Chien, Y.H. and Cheng, J.H. (2001) Effects of Light Regime. Algae in the Water, and Dietary Astaxanthin on Pigmentation, Growth, and Survival of Black Tiger Prawn Panaeus monodon Post-Larvae. Zoological Studies, 40, 371-382.

[29] Agwa, O.K. and Abu, G.O. (2014) Utilization of Poultry Waste for the Cultivation of Chlorella sp. for Biomass and Lipid Production. International Journal of Current Microbiology and Applied Sciences, 3, 1036-1047.

[30] Moyle, P.B. and Cech, J.J. (2000) Hydromineral Balance. Fishes: An Introduction to Ichthyology. 5th Edition, Prentice Hall, Englewood Cliffs, NJ, 77-93.

[31] Kasiri, M., Farahi, A. and Sudagar, M. (2012) Effects of Feeding Frequency on Growth Performance and Survival Rate of Angel Fish, Pterophyllum scalare (Perciformes: Cichlidae). Veterinary Research Forum, 2, 97-102.

[32] Gouveia, L., Rema, P., Pereira, O. and Empis, J. (2003) Colouring Ornamental Fish (Cyprinus carpio and Carassius auratus) with Microalgal Biomass. Aquaculture Nutrition, 9, 123-129. https://doi.org/10.1046/j.1365-2095.2003.00233.x

[33] Gouveia, L. and Rema, P. (2005) Effect of Microalgal Biomass Concentration and Temperature on Ornamental Goldfish (Carassius auratus) Skin Pigmentation. $A q$ uaculture Nutrition, 11, 19-23. https://doi.org/10.1111/j.1365-2095.2004.00319.x

[34] Mares, D.O.H.A. and Arce, U.E. (2017) Live Feed: Coloration and Growth Rate in Angel Fish (Pterophyllum scalare). Investigación Agropecuaria, 14, 27-33.

[35] Léger, P., Bengtson, D.A., Simpson, K.L. and Sorgeloos, P. (1986) The Use and Nutritional Value of Artemia as a Food Source. Oceanography and Marine Biology: An Annual Review, 24, 521-623.

[36] Mohanakumaran, N.C., Salin, K.R. and Ashok, K. (2007) Use of Cyclop-Eeze as a Substitute for Artemia nauplii in Larval Rearing of Giant Freshwater Macrobrachium rosenbergii (De Man 1879). Aquaculture Nutrition, 13, 88-93. https://doi.org/10.1111/j.1365-2095.2007.00457.x

[37] Biedenbach, J.M., Smith, L.L., Thomsen, T.K. and Lawrence, A.L. (1989) Use of the nematode Panagrellus redivivus as an Artemia Replacement in a Larval Penaeid 
Diet. Journal of the World Aquaculture Society, 20, 61-71.

https://doi.org/10.1111/j.1749-7345.1989.tb00525.x

[38] Martín, L., Arenal, A., Fajardo, J., Pimentel, E., Hidalgo, L., Pacheco, M., García, C. and Santiesteban, D. (2006) Complete and Partial Replacement of Artemia Nauplii by Moina micrura during Early Postlarval Culture of White Shrimp (Litopenaeus schmitti). Aquaculture Nutrition, 12, 89-96.

https://doi.org/10.1111/j.1365-2095.2006.00383.x 